accumulation of orotidine and orotic acid with increased excretion of these compounds in the urine (see Fig. 2).

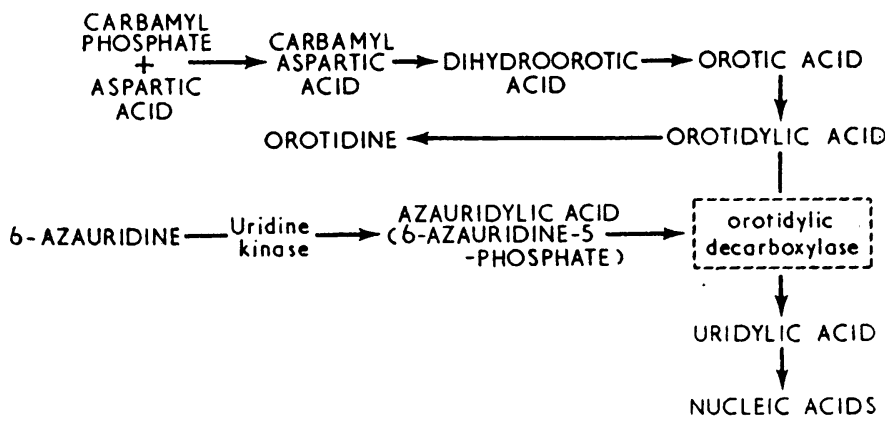

FIG. 2.-Pathways of de novo synthesis of pyrimidine nucleotides and its inhibition by 6-AzUR.

The hypocholesterolaemic effect of 6-AzUR has not previously been reported. However, Standerfer and Handler (1955) showed that the addition of 0.2 to $1 \%$ of orotic acid to the diet produced fatty livers in rats. Addition of uracil or thymine to the orotic-acid diet had no effect. Handschumacher et al. (1960b) found that the administration of adenine restored the liver lipid to normal. Rajalakshmi et al. (1961) confirmed this observation and demonstrated a depression of serum cholesterol concomitant with an accumulation of the sterol and triglyceride in the liver when $1 \%$ orotic acid was added to the diet. From estimations of ${ }^{14} \mathrm{C}$-acetate incorporation into cholesterol they concluded that depression of serum cholesterol was due to decreased synthesis in the liver and mobilization from extrahepatic tissues.

The reversal by adenine of cholesterol accumulation in the liver was ascribed to repair of an adenine deficiency resulting from accelerated nucleic-acid synthesis, itself due to the massaction effect of the expanded pyrimidine pool.

In the light of these reports it seems likely that the hypocholesterolaemia observed in four patients and in the rats treated with 6-AzUR is due to the accumulation in the body of orotic acid or one of its metabolites. It is doubtful, however, whether an excessive synthesis of nucleic acid and a consequent adenine deficiency can be invoked as a cause of the disturbance in lipid metabolism, since 6-AzUR blocks pyrimidine and hence nucleic-acid synthesis. The uricosuric effect of both orotic acid and 6-AzUR reported by Fallon et al. (1961) may be more relevant in this connexion, the excessive excretion of uric acid possibly leading to accelerated oxidation of adenine. The precise mechanism whereby 6-AzUR, orotic acid, or a metabolite influences serum and liver lipids remains unknown.

\section{Summary}

Administration of pyrimidine analogues, 6-AzUR and triacetyl-AzUR, to leukaemic patients resulted in the lowering of serum-cholesterol levels and the urinary excretion of large quantities of orotidine and orotic acid. This hypocholesterolaemia was also noted in rats given triacetyl-AzUR orally. The reason for this effect is not known.

We are grateful to Dr. N. J. Green, of Dista Products (Liverpool) Ltd., for his help with experimental studies on rats.

\section{REFERENCES}

Elves, M. W., Buttoo, A. S., Israëls, M. C. G., and Wilkinson, J. F. (1963). Brit. med. f., 1, 156.

Fallon, H. J., Frei, E., III, Block, J., and Seegmiller, J. E. (1961). ₹. clin. Invest., 40, 1906.

Handschumacher, R. E., Calabresi, P., Welch, A. D., Bono, V., Fallon, H., and Frei, E., III (1962). Cancer Chemother. Rep., 21, 1.

Cardoso, S., Jaffe, J. J., Liebow, A. A., Calabresi, P., Finch, S. C., and Welch, A. D. (1960a). Proc. Amer. Ass. Cancer Res., 3, 116. Creasey, W. A., Jaffe, J. J., Pasternack, C. A., and Hankin, L. (1960b). Proc. nat. Acad. Sci. (Wash.), 46, 178.

Rajalashi, S. Sarma, D. S. R., and Sarma, P. S. (1961). Biochem. f., 80,375 .

8ackett, G. E. (1925). 7. biol. Chem., 64, 203.

Standerfer, S. B., and Handler, P. (1955). Proc. Soc. exp. Biol. (N.Y.), $90,270$.

Wilkinson, J. F. (1963). Proc. roy. Soc. Med., 56, 644.

(1964). Practitioner, 193, 470.

\title{
Bacteriuria, Prematurity, and the Hypertensive Disorders of Pregnancy
}

\author{
K. L. STUART,* M.D., M.R.C.P., F.R.C.P.ED., D.T.M. ; G. T. M. CUMMINS, $\dagger$ M.B., M.R.C.o.G. ; \\ W. A. CHIN, $\ddagger$ M.B., B.S.
}

Brıt. med. F., 1965, 1, 554-556

It is well known that clinical pyelonephritis is a relatively common occurrence in pregnancy. Recently attention has been drawn to the high prevalence of asymptomatic bacteriuria in pregnant women (Kass, 1959). In spite of the not uncommon occurrence of eclampsia and pre-eclamptic toxaemia during pregnancy, and in spite of the well-known association of clinical pyelonephritis with hypertension, little knowledge exists of any association between symptomatic or asymptomatic infection of the urinary tract and the hypertensive disorders of pregnancy.

In this study we have established prevalence rates for bacteriuria in pregnant women attending our antenatal clinics. We have followed these subjects to term and compared the occurrence of premature delivery and the rate of emergence of

\footnotetext{
- Reader in Medicine, University of the West Indies. \$ Medical Registrar, University College Hospital, Jamaica.
}

pre-eclamptic toxaemia or other hypertensive disorders of pregnancy in bacteriuric and non-bacteriuric subjects.

\section{Materials and Methods}

Clean voided specimens of urine were collected at their first hospital visit from 2,713 consecutive pregnant women attending the antenatal clinics of the University College Hospital in Jamaica during the two-year period starting December 1961. Each urine specimen was screened initially on eosin-methyleneblue (E.M.B.) agar. Quantitative bacterial counts were carried out on urines which showed growth on this media and the counts were repeated in subjects with counts of 100,000 or more per ml. of urine. Two or more consecutive counts at this level were regarded as indicative of significant bacteriuria as defined 
by Kass (1959). Each subject was followed to term. The rates of occurrence of pre-eclamptic toxaemia and/or hypertensive disease of pregnancy and of prematurity were noted in bacteriuric and non-bacteriuric subjects.

Subjects with diastolic pressure greater than $85 \mathrm{~mm}$. Hg at the time of the first examination or who were known to have a past history of hypertension were regarded as having essential or pre-existing hypertension and were not studied further. This study was designed to determine the number of subjects in whom hypertension developed for the first time during the course of pregnancy. These were classified as hypertensive disorders of pregnancy and included (1) subjects developing hypertension alone, and (2) subjects with pre-eclamptic toxaemia or eclampsia-that is, hypertension occurring in association with albuminuria, oedema, and/or convulsions. Hypertension of pregnancy was defined as a rise of diastolic pressure above $100 \mathrm{~mm} . \mathrm{Hg}$ in subjects whose blood-pressure had been normal at the onset of the study. The observer who classified subjects into these categories had no knowledge of the bacteriuria status of the subjects at the time the classification was made.

Infant birth weights of less than $5 \mathrm{lb} .8 \mathrm{oz} .(2.5 \mathrm{~kg}$.) are regarded as premature by international agreement, irrespective of the apparent period of gestation. These criteria for prematurity were followed in this study.

\section{Results}

Of 2,713 subjects, $95(3.5 \%)$ were positive for bacteriuria. The prevalence of bacteriuria was lowest in the lowest and highest in the highest age and parity groups (Figs. 1 and 2).

Of the 95 bacteriurics, seven have not reattended the clinic and cannot be traced. Details of the remaining 88 and of the first 729 consecutive controls who have been followed to term are given in the Table. Eighty-three $(11.4 \%)$ of the 729

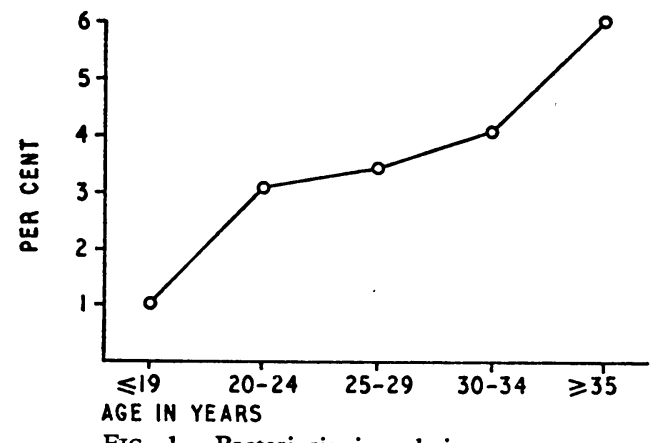

FIG. 1.-Bacteriuria in relation to age.

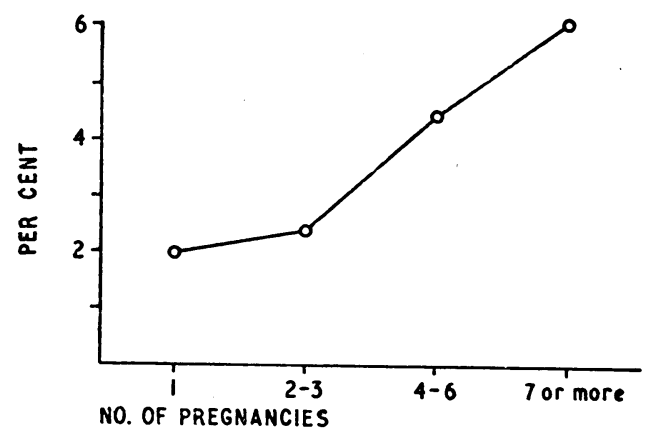

FIG. 2.-Bacteriuria in relation to parity.

controls and $20(22.8 \%)$ of the 88 bacteriurics had premature deliveries. The $\mathrm{P}$ value for this difference is less than 0.025 . Hypertensive disease of pregnancy occurred in $33(4.5 \%)$ of the controls and $16(18.2 \%)$ of the bacteriurics $(P<0.001)$.

In all age-groups the occurrence of prematurity (Fig. 3) and hypertensive disease of pregnancy (Fig. 4) was more pronounced in subjects than in controls. The prevalence of hypertensive disease of pregnancy rose particularly rapidly with age in bacteriurics and only insignificantly in controls. A comparable rise in the prevalence of hypertensive disease and prematurity occurred in bacteriurics in the higher parity groups when compared with controls.

Of the 88 bacteriurics, 12 (13.5\%) developed clinical signs and symptoms of overt pyelonephritis during pregnancy and were treated. By contrast only $8(1.1 \%)$ of the 729 nonbacteriurics developed symptoms of urinary-tract infection during their pregnancy.

Prematurity and Hypertensive Disease of Pregnancy in Bacteriurics and Controls

\begin{tabular}{|c|c|c|c|c|c|c|}
\hline & & \multirow{2}{*}{$\begin{array}{l}\text { No. of } \\
\text { Subjects }\end{array}$} & \multicolumn{2}{|c|}{ Prematurity } & \multicolumn{2}{|c|}{$\begin{array}{l}\text { Hypertensive Discase } \\
\text { of Pregnancy }\end{array}$} \\
\hline & & & No. & $\%$ & No. & $\%$ \\
\hline \multirow[t]{2}{*}{$\begin{array}{l}\text { Controls } \\
\text { Bacteriurics ... }\end{array}$} & 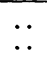 & $\begin{array}{r}729 \\
88\end{array}$ & $\begin{array}{l}83 \\
20\end{array}$ & $\begin{array}{l}11 \cdot 4 \\
22 \cdot 8\end{array}$ & $\begin{array}{l}33 \\
16\end{array}$ & $\begin{array}{r}4 \cdot 5 \\
18 \cdot 2\end{array}$ \\
\hline & & & \multicolumn{2}{|c|}{$P<0.025$} & \multicolumn{2}{|c|}{$P<0.001$} \\
\hline
\end{tabular}

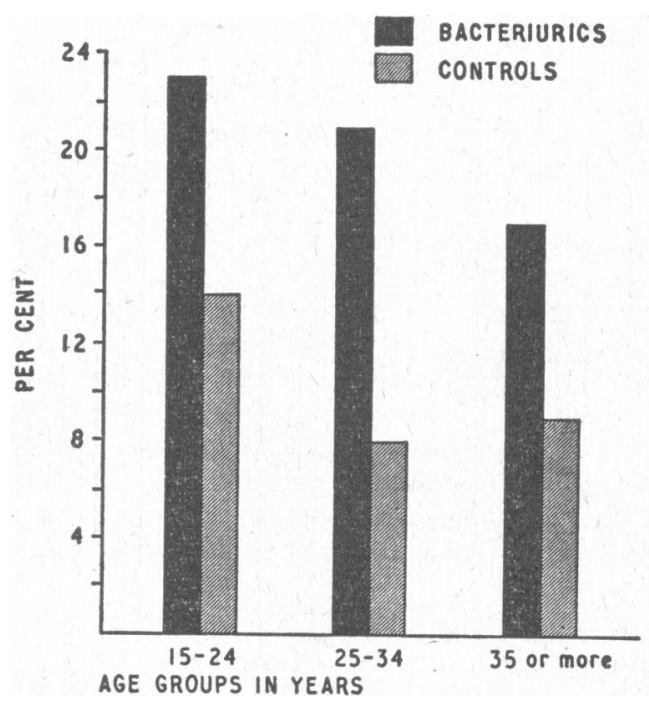

Fig. 3.-Prematurity by age in bacteriurics and controls.

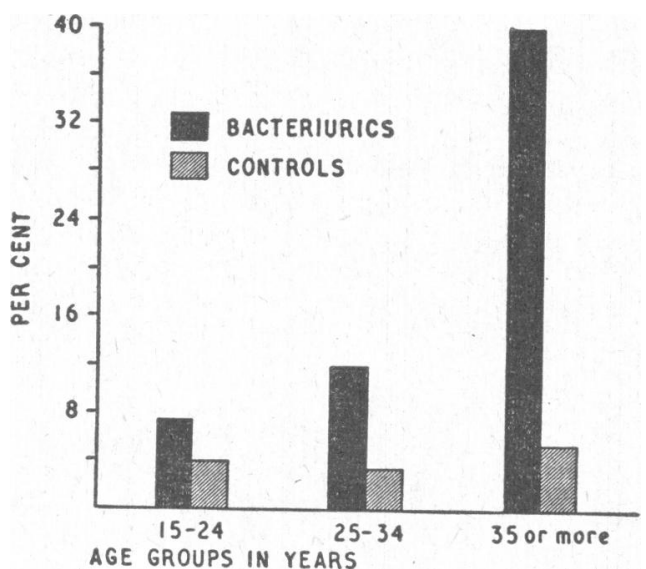

Frg. 4.- Hypertension by age in bacteriurics and controls.

\section{Discussion}

Varying prevalence rates for infection of the urinary tract during pregnancy have been given. Baird (1936) reported that $20 \%$ of primigravidae admitted to his hospital had pyelonephritis. - Kass (1959) reported symptomless bacteriuria in $6 \%$ of normal pregnant women. Clinical pyelonephritis occurred in $40 \%$ of these subjects with symptomless bacteriuria. 
Prevalence rates as low as $2 \%$ have also been given (Traut, 1937 ; Mussey and Lovelady, 1940). Some of these rates are for predominantly symptomatic, others are for essentially asymptomatic, infections of the urinary tract. The widely different prevalence rates are therefore not unexpected. Apart from the effect of age and parity (Kass, 1959 ; Kass, Miall, and Stuart, 1961), there is evidence that social and economic circumstances may also affect the rates of bacteriuria (Kass, personal communication, 1963).

The significantly higher prevalence rates of clinically overt pyelonephritis in bacteriurics as compared with non-bacteriurics indicate the predictive value of bacterial counts in the urine as an index of infection of the urinary tract.

With respect to prematurity, our findings merely confirm and extend earlier observations that the occurrence of prematurity was higher in subjects with bacteriuria (Kass, 1959) and clinical urinary-tract infection (Baird, 1936) than in normal controls. Whether or not this increased occurrence of prematurity in bacteriurics is the result of higher rates of hypertensive disease of pregnancy, rather than of urinary-tract infection per se, must await the results of further work. However, the implication is inescapable that, with the detection and successful treatment of bacteriuria during pregnancy, not only may the occurrence of clinical pyelonephritis be reduced but much of the foetal morbidity and mortality associated with hypertension and prematurity may be eliminated.

In recent studies we have found that blood-pressure levels were disproportionately higher in women in Jamaica than in Wales (Miall, Kass, Ling, and Stuart, 1962). Women with symptomless bacteriuria were also shown to have higher bloodpressure levels than non-bacteriuric controls (Kass et al., 1961). It was partly the difficulty of determining in this study whether the bacteriuria was the cause or consequence of hypertension which prompted us to investigate the possible role of bacteriuria in the production of hypertension in pregnancy in Jamaica. It was clearly an advantage in this study to be able to establish accurately the blood-pressure status of our patients at the onset of the study, and to be able to exclude pre-existing hypertensives from the analysis.

In earlier studies attention has been drawn to a possible relation between pyelonephritis and the toxaemias of pregnancy. Peters, Lavietes, and Zimmerman (1936) reported that necropsies performed on 25 patients with known toxaemia demonstrated pyelonephritis in $44 \%$; and Finnerty (1956) has drawn attention to the possibility that pyelonephritis may masquerade as toxaemia of pregnancy. The significantly higher occurrence of toxaemias of pregnancy in bacteriurics as compared with controls in our study would clearly suggest that, in the pregnancy toxaemias at any rate, bacteriuria may be the cause and not the effect of hypertension. These findings, of course, cannot answer the question of whether pyelonephritis leads to pre-eclamptic toxaemia or merely simulates it. Nor is there any evidence at present that our observations necessarily relate to blood-pressure levels in the general population. We can only state (1) that when the accepted criteria for the diagnosis of hypertension and toxaemia of pregnancy are applied there is a higher prevalence of these disorders in bacteriurics than in non-bacteriurics; (2) that in bacteriurics there is a steep rise in prevalence with increasing age and increasing parity; and (3) that these observations are in accord with our earlier observations on bacteriuria in relation to hypertension in women in the general population.

Although our conclusions from these observations must remain speculative, we wonder whether asymptomatic infection of the urinary tract in women, increasing in incidence with age and/or parity, may not be the factor which accounts for the accelerated rise of blood-pressure with age in women as compared with men which has been noted in most studies of the epidemiology of hypertension. The far higher prevalence rates for bacteriuria in women as compared with men noted in previous studies (Stuart, 1960) would also lend support to this hypothesis.

\section{Summary}

The occurrence of prematurity and the hypertensive disorders of pregnancy in bacteriuric and in non-bacteriuric women has been compared.

In all age and parity groups the occurrence of prematurity and the hypertensive disorders of pregnancy was higher in bacteriurics than in non-bacteriurics. Prevalence rates for the emergence of the hypertensive disorders of pregnancy rose particularly rapidly with increasing age and parity in bacteriuric subjects.

The predictive value of bacteriuria as an index of subsequent clinical pyelonephritis has been confirmed.

The possible implications of these observations are discussed. it is suggested that some of the perinatal mortality and morbidity associated with hypertension and prematurity may be preventable.

It is a pleasure to record our thanks to Dr. E. H. Kass for his assistance and advice. This work was supported by grants from the Princess Alice Appeal Fund of the University College Hospital, Jamaica, and from the National Institutes of Health of the United States Public Health Service (AM-06767-01).

\section{REFERENCES}

Baird, D. (1936). F. Obstet. Gynaec. Brit. Emp., 43, 435.

Finnerty, F. A. (1956). F. Amer. med. Ass., 161, 210.

Kass, E. H. (1959). In International Symbosium on Biology of Pyelonephritis, edited by E. L. Quinn and E. H. Kass, p. 399. Boston, Mass.

Miall, W. E., and Stuart, K. L. (1961). 7. clin. Invest., 40, 1053.

Miall, W. E., Kass, E. H., Ling, J., and Stuart, K. L. (1962). Brit. med. f., $2,497$.

Mussey, R. D., and Lovelady, S. B. (1940). Amer. F. Obstet. Gynec., 39, 236

Peters, J. P., Lavietes, P. H., and Zimmerman, H. M. (1936). Ibid., 32,

911. Stuart, K. L. (1960). Lancet, 1, 1021.

Traut, H. F. (1937). Amer. F. Surg., 35, 273. 